\title{
FOODWAYS THROUGH CERAMICS IN SOUTHEAST ASIAN ARCHAEOLOGY: A VIEW FROM SOUTHERN VIETNAM
}

\author{
Michelle S. Eusebio
}

\author{
Department of Anthropology, University of Florida
}

meusebio@ufl.edu

\begin{abstract}
Food related research in Southeast Asian archaeology is heavily biased towards the assessment of subsistence strategies as well as typological and petrographic analyses of ceramics. Little is known about the range of diverse food items, how they were prepared and consumed, and the importance these foods played in the social lives of people in the past. My research seeks to extend the treatment of food in Southeast Asia archaeology from subsistence "strategies" to foodways by incorporating technofunctional and organic residue analyses of earthenware pottery vessels to address outstanding questions about their function with regard to the preparation and consumption of food. This paper presents preliminary findings on a range of prehistoric earthenware pottery excavated from Rach Núi, An Son (Neolithic), and Gò Ô Chùa (Metal Age) sites in Long An Province, Southern Vietnam. Results are compared with similar data from experimental and ethnographic pottery as well as integrated with complementary data associated with the archaeological pottery samples. It is predicted that integrative analysis of technofunctional aspects of earthenware pottery with organic residue analysis will provide new perspectives on the foodways in Southern Vietnam during the Neolithic and Metal Age.
\end{abstract}

\section{INTRODUCTION}

In the prehistory of Southeast Asia (SEA), work has mainly focused on subsistence "strategies" of food production and procurement as well as the identification of the earliest agricultural products and domestic animals to enter the region (e.g., Bellwood 2005; Higham 2014; Piper et al. 2012; Weber et al. 2010). Meanwhile, the majority of published and accessible works on earthenware ceramics from archaeological sites in SEA have focused on typology and petrographic analyses, with emphasis on identifying transregional similarities in form and decoration that help to establish patterns of human migration and contact (e.g., Rispoli 2007). Some ethnographic accounts and studies on how local communities in SEA utilize ceramics in food preparation and distribution have been conducted (e.g., Skibo 1992). However, it is not clear how food items were prepared and served in conjunction with ceramics that would allow for constructive discussion of food in relation to social diversity, especially during the SEA Neolithic and Metal Age (3000 BC-AD 500). Building on the previous and existing works in SEA, my research seeks to transcend details of 'subsistence strategies' as well as "culture history" to address the linkages between ceramics/pottery and foodway practices by focusing on the function and contents of pottery in prehistory. It adopts the growing advocacy in anthropological archaeology to build upon research focused on food acquisition and diet, by placing increased emphasis on ancient foodways (Atalay and Hastorf 2006) and social diversity (Twiss 2012). Foodways comprise the interconnected stages of "the production and procurement, processing, cooking, presentation, and eating" (or consumption) of food (Atalay and Hastorf 2006: 283), including disposal of food refuse and associated material culture (Twiss 2012). Each stage of foodways is a different stage of human-food interaction (Twiss 2012).

In relation to the above, this paper introduces my research on the archaeology of foodways in Neolithic and Metal Age Southeast Asia (SEA), focusing on the role of ceramics in the preparation and serving of food. It also presents preliminary findings from sampled earthenware pottery excavated from prehistoric sites in Long An Province, Southern Vietnam. Results are compared with similar data from experimental and ethnographic pottery as well as integrated with complementary data associated with the archaeological pottery samples.

\section{APPROACHES TO FOODWAYS THROUGH CERAMICS}

For the purposes of investigating the archaeology of foodways in Neolithic and Metal Age SEA through 
ceramics, this research incorporates technofunctional analysis of form, technology, and use-alteration, as well as organic residue analyses of earthenware pottery for former contents to address outstanding questions about their function with regard to the preparation and consumption of food.

\section{Technofunctional Analysis}

Technofunctional analysis includes the (a) analysis of technology and form of pottery vessels to infer intended use or function and (b) use-alteration analysis (surface attrition and carbon deposition) for inferring actual use (Hally 1983; Kobayashi 1994; Orton et al. 1993; Rice 1987; Rye 1981; Skibo 1992, 2013). Aside from possible intended and actual function, technofunctional analysis can also address the "affordances" (Knappett 2005) or suitability of pottery vessels to perform multiple functions (Gibbs and Jordan 2013). One may ask, are the vessels the "Swiss Army Knife of the pottery world" (Skibo 2013: $105) ?$

\section{Organic Residue Analysis of Pottery}

The analysis of organic residues in archaeological pottery (Evershed 2008; Heron and Evershed 1993) can clarify the association of pottery with different types of food items and past foodway practices (e.g., Craig et al. 2011, 2013; Cramp et al. 2014). Organic residues that survived as actual contents, surface residues, and absorbed residues in pottery vessels offer a plethora of information on contents, function, local and regional economies, and technologies (Evershed 2008; Heron and Evershed 1993). Evershed (2008: 6) defined the analysis of organic residues as a field that "utilizes analytical organic chemical techniques to identify the nature and origins of organic remains that cannot be characterized using traditional techniques of archaeological investigation." This analysis is guided by the Archaeological Biomarker Concept, which states that the molecular structure and isotopic compositions of key components or the "chemical fingerprint" of residues can be related to the compositions of plants and animals exploited by humans in the past (Evershed 2008). In SEA, similar types of analysis have already been conducted at a handful of Neolithic and Metal Age sites (e.g., Hauman 2012 for Thailand; Yang and March 2012 for Taiwan).

\section{Technofunctional and Organic Residue Analyses}

Technofunctional and organic residue approaches are suitable to contextualize a direct relationship between both pottery production and use, and the preparation and consumption of different food products (e.g., Jones 1999; Stockhammer 2012). My research seeks to assess how was pottery utilized during the Neolithic and Metal Age in Southeast Asia based on the attributes (form and function) of pottery and the food items prepared and/or served on them. One may ask - what was pottery's association with different subsistence strategies, such as cereal agriculture, management and/or hunting of terrestrial animals, and/or fishing? For example, the organic residue analysis of pottery with charred surface residues demonstrated that the Jomon foragers of Japan used pottery to process marine and freshwater products (Craig et al. 2013), associating pottery use with fishing. From a different perspective, organic residue analysis can also address how pottery was "entangled" (Gibbs and Jordan 2013; Hodder 2012) with food and people. How were people dependent on pottery to prepare and serve their food? For example, Copley et al. (2005, as cited by Hodder 2012) demonstrated the entanglement between the people in Çatal Höyük and their cooking pots with associated small ruminant animals (probably domesticated sheep and goat), where the pots were used to process fats from these animals. In SEA, we can also ask how "entangled" pottery was with the food members of the "Neolithic Material Culture Package," which are the domesticates brought by the migrating farmers, and/or other food sources that can be foraged from surrounding environments? How people during the prehistory in Southeast Asia were dependent on their pottery to prepare and serve their food?

I am also concerned with the spatial and temporal differences in the way diverse communities across the region processed, cooked, and served their food. It is hypothesized that there is a correlation between detected food contents and inferred function of pottery across sampled archaeological sites, which will demonstrate the social diversity based on foodway practices across space and time. This will show the spatial and temporal differences in the way diverse communities processed, cooked, and served their food. This is demonstrated by the case of Northern Europe. In the Baltic region, Craig et al. (2011) demonstrated that marine and freshwater resources continued to be exploited and prepared in pottery during the agricultural transition. Their findings suggest that the introduction of domestic products did not have an impact on how "traditional" foodstuffs were consumed, but rather complemented their continued use. In contrast, the same method coupled with isotopic analysis of stable carbon isotope ratios of human and faunal bone collagen demonstrated that the early farmers in the neighboring Northeast Atlantic archipelago rejected the exploitation of marine resources and adopted dairy farming (Cramp et al. 2014). These contrasting findings in northern Europe during the transition to agriculture demonstrate that organic residue analysis can assess the diversity of foodway practices and the process of Neolithization in a defined geographic region. Cramp et al. (2014) also showed that from the Bronze Age to the Viking Age in Northeast Atlantic, there was an increase in the exploitation of aquatic resources and a decline in the preparation of dairy products in pottery.

As a response to the advocacy for future studies of sociocultural diversity based on wider environmental and technological approaches in SEA (White 2011), my research seeks to examine the diversity of foodway practices as a proxy to sociocultural diversity across space and time in prehistoric SEA. From social diversity, 


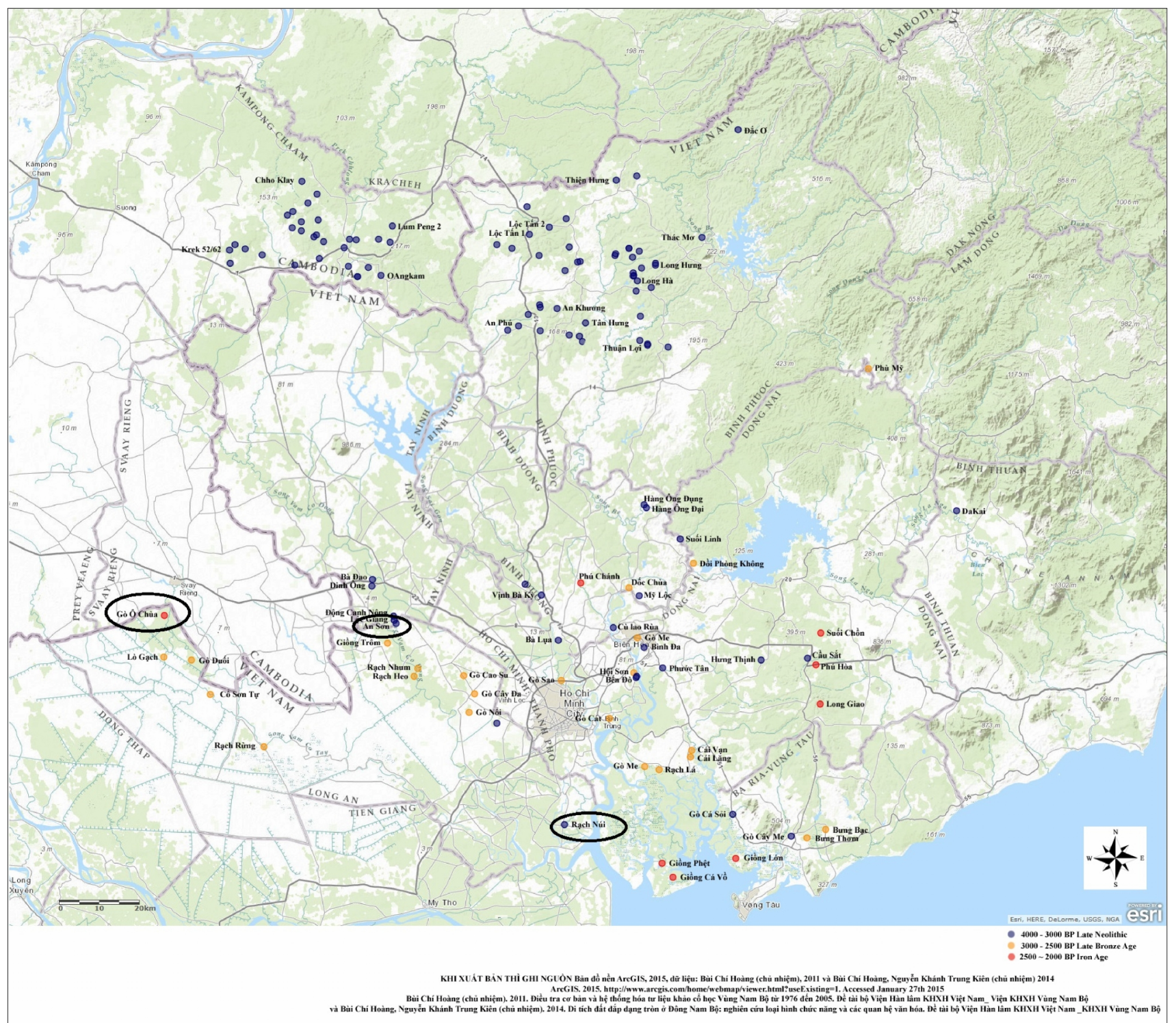

Figure 1: Map of Mekong Delta in southern Vietnam, indicating the locations of Rach Núi, An Sơn, and Gò Ô Chùa sites in oblongs. Courtesy of Tran Thi Kim Quy and Dang Ngoc Kinh.

identity in terms of economic [sic], status, ethnic, gender, and religious distinctions" can also possibly be addressed (after Twiss 2012: 357).

\section{THE SITES AND FOOD CANDIDATES IN SOUTHERN VIETNAM}

The earthenware pottery samples examined were excavated from three archaeological sites in Long An Province, southern Vietnam (Figure 1), which are Rạch Núi, An Sơn, and Gò Ô Chùa sites. The Rạch Núi site is a Neolithic mound dating to 1500-1200 cal BC near a tributary of the Mekong River and excavated in MarchApril 2012 (Piper et al. 2014). The An Sơn site is also a Neolithic mound dating to $2200-1300 \mathrm{cal}$ BC. It is located in An Ninh Tay commune, Duc Hoa District, Long An Province, 300 m east of the Vam Co Dong River, and in a valley north of the Mekong Delta (Bellwood et al. 2011). The Gò Ô Chùa site is an occupational site since the Early
Bronze Age (ca. 1000-500 cal BC). It is located at the Vietnamese-Cambodian border area (Reinecke 2012).

The subsistence strategies during the Neolithic in Mainland Southeast Asia (MSEA) are known to be rice and millet farming, animal management, as well as terrestrial and maritime foraging (Higham 2014; White 2011). These are the same subsistence strategies employed during the Bronze Age, when metal tools for fishing and food processing were introduced, and the Iron Age, when people were also involved in the salt making industry (Higham 2002). Interpretations of subsistence patterns in Southeast Asian prehistory are partly derived from the analyses of animal and plant remains. Awareness of these analyses is needed in order to contextualize the findings from organic residue analysis of earthenware vessels from prehistoric sites in the region.

The possible food sources prepared and served during the Neolithic and Metal Age in MSEA, especially 
Southern Vietnam, are domesticated plants and animals, wild terrestrial and aquatic animals (Blench 2015, Campos 2014; Piper and Amano 2014; Piper et al. 2012; Reinecke pers. comm. 2013), other livestock, other plant sources (Blench 2015), and beans (Castillo and Fuller 2010). It has been cogently argued that the domesticated plants and animals were introduced as part of the Neolithic material culture package by the Austroasiatic speaking farmers who migrated from a northern homeland (Bellwood 2005). These are pig, dog (Piper et al. 2012), rice (Bellwood et al. 2011), millet (Castillo 2014), and chicken (Berthouly-Salazar et al. 2010). Examples of wild food resources are freshwater fish (Campos 2014; Piper et al. 2012) turtles, shellfish, crabs, reptiles, monkeys, and deer (Piper et al. 2012; Piper and Amano 2014). Other livestock would include duck, goose, goat, cow, and buffalo. Other plant sources would include taro, sesame, banana, and betel pepper (Blench 2015). The beans (mungbean and horsegram) were introduced into MSEA from South Asia during the Iron Age (Castillo and Fuller 2010).

This research is coordinated with active zooarchaeological and paleobotanical research (Piper et al. 2012; Piper et al. 2014), and will complement ongoing studies of the pottery assemblages recovered from these sites (e.g., Sarjeant 2012a,b). The technofunctional analysis component is critical to address how foods were prepared in and/or served on sampled pottery vessels. Functional categories of sampled vessels focuses on form (restricted pot, unrestricted pot, jar, open bowl, restricted bowl, or small cup and/or bowl) and function (processing, storage/transfer, cooking, or serving). It is possible that there is a correlation between form, function and identifiable food categories (terrestrial animals, aquatic resources, and plants), which will underscore patterns of foodway practices in prehistoric southern Vietnam. For example, in present-day southern Vietnam, I observed that cooking pots in the form of open bowls are only used to prepare and serve a fish stew. This specific practice is among one of many observed differences of southern Vietnam compared to central and northern Vietnam. This example, then, presents a possibility that an association between a specific pottery form and function with identified food categories can be examined archaeologically.

\section{MATERIALS AND METHODS}

My participation in the post-excavation work of the institutions that I am collaborating with was part of my predissertation research in late 2012. I selected and collected the pottery samples recovered during the 2008, 2009, and 2012 excavations of Gò Ô Chùa, An Sơn, and Rach Núi sites in the storage of Long An Provincial Museum (Suppl. Fig. S1). In conjunction with the building of reference collection for freshwater fish from Southern Vietnam by Fredeliza Campos, experimental cooking activities with freshwater fish using three locally manufactured earthenware pots and a stove were done in the backyard of Long An Museum. The first pot was used to cook by boiling five varieties of fish (Figure 2, Suppl. Fig. S2). The second pot was used to cook two dishes (Suppl. Fig. S3). The third pot was used to cook different varieties of fish by frying and boiling (Figure 3, Suppl. Fig. S3). Since there are restaurants in Southern Vietnam that use earthenware pots to prepare and serve some traditional dishes, we took an opportunity to collect the clay pot used to serve Cá Kho Tộ or braised caramelized fish in Phong An restaurant (Figure 4, Suppl. Fig. S4). We also interviewed the owner of a Thuy Ta restaurant about the use of clay pots in preparation and serving of food, consequently leading to the collection of another pot used to serve Cá Kho Tộ (Suppl. Fig. S4). The interview is part of the ethnoarchaeological survey on the food related activities of people using earthenware ceramics with approval from Institutional Review Board (Protocol \#2012-U-1089).

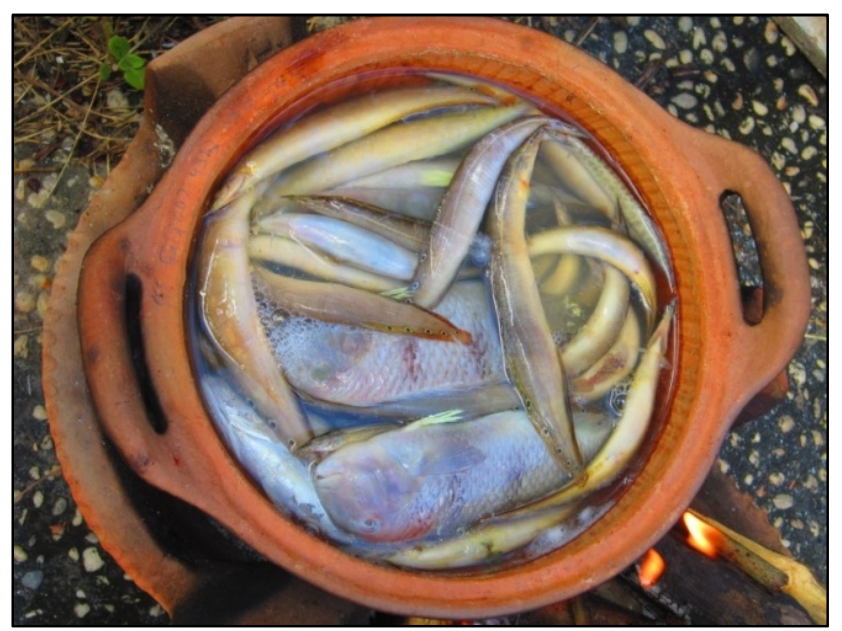

Figure 2: Boiling a variety of freshwater fish in the experimental cooking pot (E7).

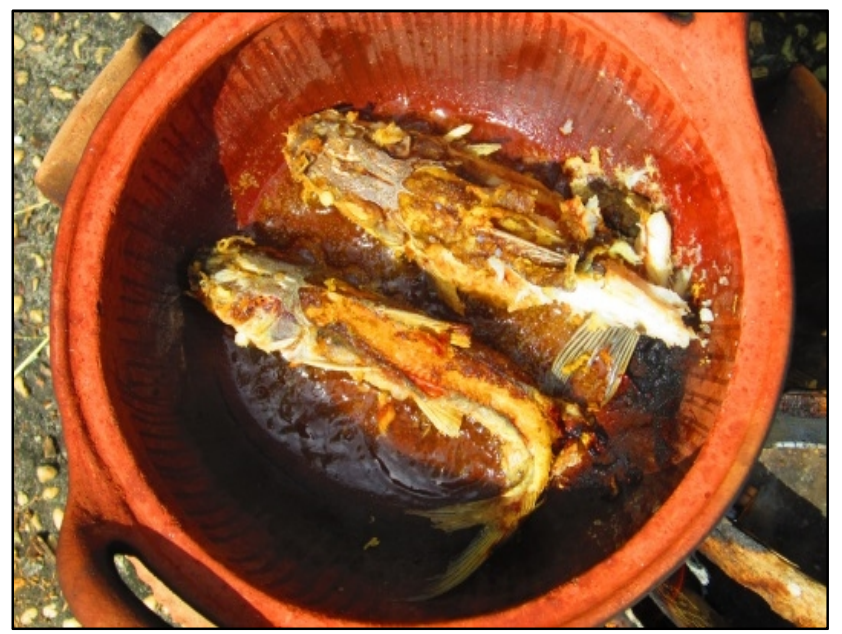

Figure 3: Frying fish in the third pot used for frying and boiling.

The archaeological pottery samples were documented with technofunctional analysis. The experimental pot used for cooking several types of freshwater fish caught from the tributaries of Mekong River system, two ethnographic pots, and six archaeological samples from Southern 
Vietnam underwent the extraction process for lipid residues and were analyzed with gas chromatographymass spectrometry (GC-MS) as fatty acid methyl esters (FAMEs). The archaeological samples are two rim sherds from Rạch Núi site, two body sherds from An Sơn site, and a shoulder and body sherd from Gò Ô Chùa site. Detailed methods on technofunctional and organic residue analyses are found in Supplementary Materials I and II, respectively.

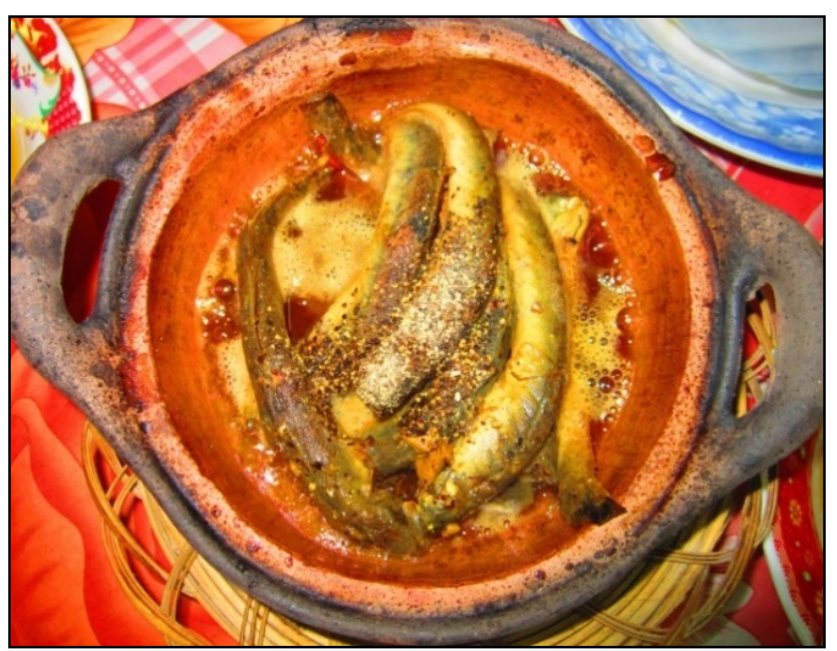

Figure 4: Clay pot used to serve Cá Kho Tọ or braised caramelized fish in Phong An restaurant.

\section{RESULTS AND DISCUSSION}

\section{Technofunctional Analysis}

Based on the 133 samples with rims collected from Rạch Núi (70), An Sơn (29), and Gò Ô Chùa (34) sites in Southern Vietnam (Table 1), the average orifice diameter and lip thickness of those from Rạch Núi are, respectively, smaller and larger than those from other two sites. Those from An Sorn have the lowest average rim thickness. Those from Gò Ô Chùa have the narrowest range of orifice diameters. The frequency distributions of orifice diameters for the three sites are shown in Supplementary Figures 5-7.

When the samples with rims were sorted according to their vessel forms (Table 2, Suppl. Fig. S8), the majority of them are restricted pots $(43.61 \%$, Figure 5). Other forms are open bowls $(21.80 \%)$, restricted bowls $(5.26 \%)$, open pots $(3.00 \%)$, restricted pots/jars (19.55\%), jars $(3.00)$, stove $(2.26 \%)$, and small cups and/or bowls $(2.26 \%)$. For the purpose of this research, the classification of vessel forms was adopted and modified from the one followed in the Florida Gulf coast (see Wallis 2011; Wiley 1949), which can easily be reconciled with the classification systems being used already in Southeast Asia (specifically for southern Vietnam, see Sarjeant 2012a,b). Restricted pots are restricted vessels with their height greater than their maximum width, which is somewhere between the opening and the base of the vessels. Open pots are similar to restricted pots but their maximum width is at their unrestricted opening. Open bowls are unrestricted vessels with their height less than their maximum width, which is at the opening. Restricted bowls are similar to open bowls but their maximum width is somewhere between the opening and the base of the vessels. Small cups and/or bowls are smaller versions of pots and bowls, respectively. Restricted pots/jars could be small jars of about $30 \mathrm{~cm}$ tall as archaeologists working in Vietnam would classify them, which have orifice diameters of 12-17 cm. Jars were classified based on the knowledge of the shape of modern ethnographic and archeological earthenware jars in the region (see Miksic 2003). They are similar to restricted pots but have thicker walls and are taller than regular restricted pots (Rice 1987). Stoves are classified and labelled as $\mathrm{ca}$ rang by the archaeologists who excavated the above-mentioned sites. These are used as equipment for cooking with wood and fire, rather than as vessels for food. Without soot and/or labels, their rim fragments can be classified as open bowls based on their profiles.

Table 1: Orifice diameter and rim thickness summary statistics of vessels with rims collected from three archaeological sites in the Long An Province, Southern Vietnam.

\begin{tabular}{ccccc}
\hline Site & $\begin{array}{c}\text { Orifice } \\
\text { Diameter } \\
(\mathrm{cm})\end{array}$ & $\begin{array}{c}\text { Rim } \\
\text { Thickness } \\
(\mathrm{mm})\end{array}$ & $\begin{array}{c}\text { Lip } \\
\text { Thickness } \\
(\mathrm{mm})\end{array}$ \\
\hline Rach & $N$ & 70 & 70 & 70 \\
Núi & Mean & 17.7 & 8.33 & 6.09 \\
& Std. Dev. & 4.06 & 1.74 & 1.32 \\
& Minimum & 11 & 4.50 & 2.44 \\
Maximum & 36 & 11.72 & 9.36 \\
Sơn & $N$ & 29 & 29 & 29 \\
& Mean & 24.52 & 7.78 & 7.88 \\
& Std. Dev. & 7.79 & 2.28 & 2.0 \\
& Minimum & 12 & 3.71 & 4.4 \\
& Maximum & 40 & 12.52 & 14.14 \\
Gò Ô & $N$ & 32 & 34 & 34 \\
Chùa & Mean & 20.16 & 9.26 & 9.52 \\
& Std. Dev. & 3.97 & 2.76 & 2.85 \\
& Minimum & 12 & 5.01 & 5.95 \\
& Maximum & 28 & 18.57 & 19.37 \\
\hline
\end{tabular}

Table 2: Summary of vessel forms of pottery samples with rims collected from three archaeological sites in the Long An Province, Southern Vietnam.

\begin{tabular}{|c|c|c|c|c|}
\hline Vessel form & $\begin{array}{l}\text { Rạch } \\
\text { Núi }\end{array}$ & $\begin{array}{l}\text { An } \\
\text { Sơn }\end{array}$ & $\begin{array}{l}\text { Gò Ô } \\
\text { Chùa }\end{array}$ & Total \\
\hline Open bowls (21.80\%) & 6 & 14 & 9 & 29 \\
\hline $\begin{array}{c}\text { Restricted bowls } \\
(5.26 \%)\end{array}$ & 1 & 2 & 4 & 7 \\
\hline Open pots $(3.00 \%)$ & 3 & 0 & 1 & 4 \\
\hline $\begin{array}{c}\text { Restricted pots } \\
(43.61 \%)\end{array}$ & 38 & 5 & 15 & 58 \\
\hline $\begin{array}{c}\text { Restricted pots/Jars } \\
(19.55)\end{array}$ & 20 & 5 & 1 & 26 \\
\hline Jars $(3.00 \%)$ & 0 & 0 & 4 & 4 \\
\hline Stove $(2.26 \%)$ & 0 & 3 & 0 & 3 \\
\hline $\begin{array}{c}\text { Small cups/bowls } \\
(2.26 \%)\end{array}$ & 2 & 1 & 0 & 3 \\
\hline Total $(100 \%)$ & 70 & 29 & 34 & 133 \\
\hline
\end{tabular}

The use alterations from the samples are presence of soot, firing clouds, pedestalled tempers, and non-abrasive 
surface attritions (pitting and surface erosions, after Vukovic 2012). Only two vessel samples have presence of soot due to cooking activities. One is a body sherd from Gò Ô Chùa with charred interior surface residues (Figure 6), which are possibly burnt food remains. Another consists of fragments of a stove from An Son with charred interior surface residues (Figure 7), which are possibly due to firewood used for cooking. Many samples have firing clouds that could be due to cooking activities and/or firing of pottery (Figure 8). Pedestalled tempers are commonly found in samples with organic and lime tempering materials. The non-abrasive surface attritions (pitting and surface erosions, after Vukovic 2012, Figure 9) were observed from the interior surfaces of two samples from Rach Núi, two from An Sơn, and four from Gò Ô Chùa. This could possibly be due to a fermentation process (Vukovic 2012). It is possible that the sherd samples with eroded interior surfaces came from vessels used to prepare and/or serve fermented food items, similar to the making of fish sauce by fermenting fish and salt in present-day Vietnam.

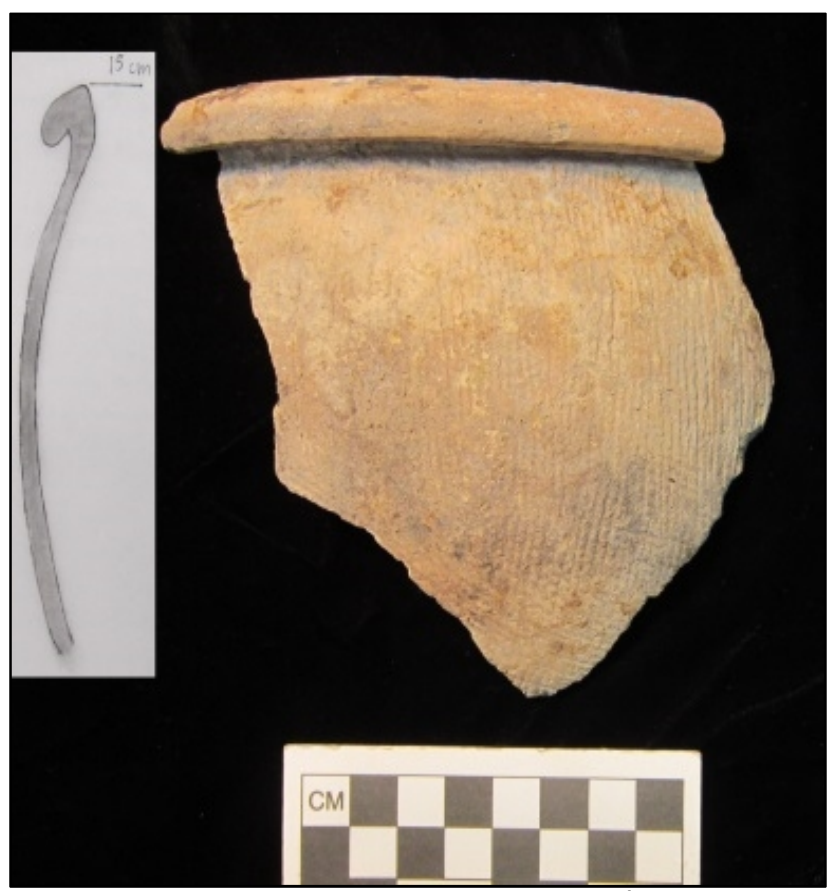

Figure 5: An example of restricted pot from Gò Ô Chùa, Trench 2, Layer 11.

Tempering materials observed from the samples are organic (probably rice husks), sand, grog, shell, lime (or limestone), with various textures, percentage abundances, and combinations. The potters had used a single material or a combination of various kinds of temper. For cooking pots, organic or fiber temper could have been used for their manufacture to improve their heat conductivity. Since organic tempers leave pores after the firing of the pottery vessels, they were also utilized for making jars for storage. These pores allow water to permeate the vessel walls and evaporate, resulting in the cooling of water or any liquid inside the jar (Schiffer and Skibo 1987). These can be attested by the samples identified as restricted pots, jars, and restricted pots/jars from An Sơn and Gò Ô Chùa sites. Other temper materials (sand, grog, shell, lime, and limestone) could have also been used for improving the workability of the clay and thermal shock resistance of pottery (after Bronitsky and Hamer 1986; Rye 1976).

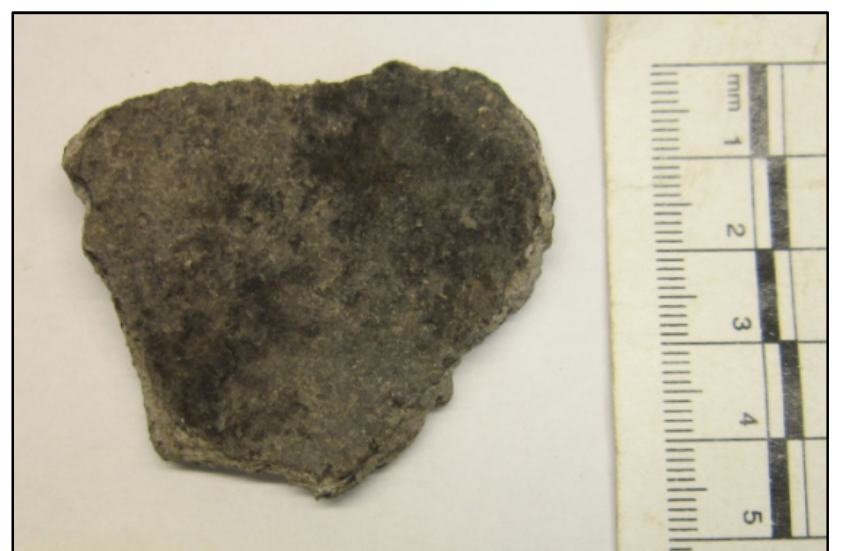

Figure 6: A body sherd from Gò Ô Chùa, Trench 1, Layer 10.

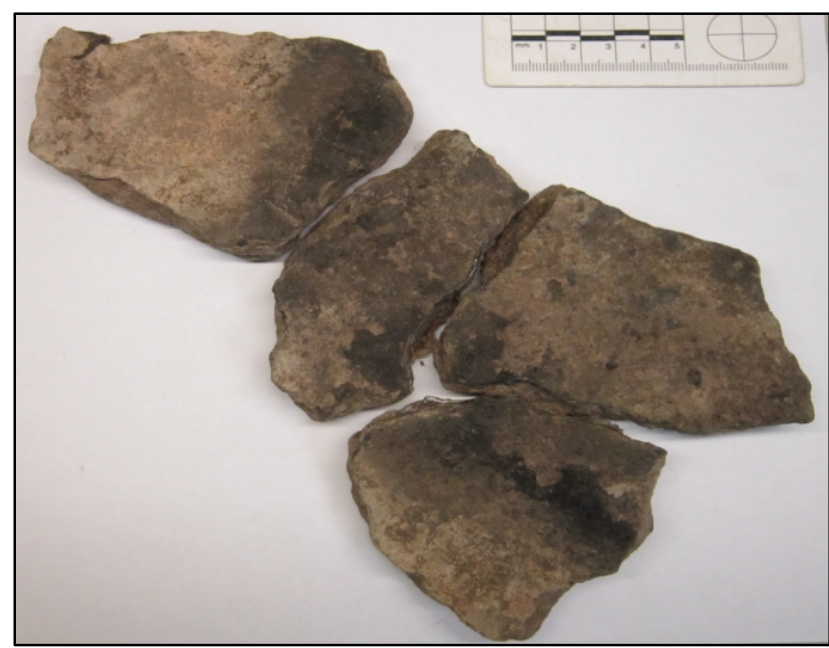

Figure 7: A stove from An Son, Trench 1, Layer 10 with charred interior surface residues.

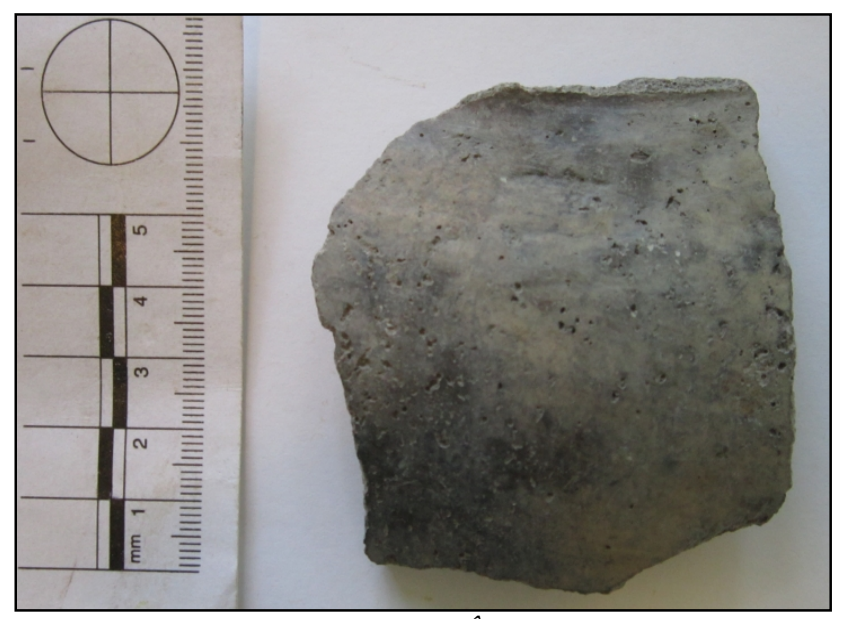

Figure 8: A pottery sherd from Gò Ô Chùa, Trench 1, Layer 11 with firing cloud. 

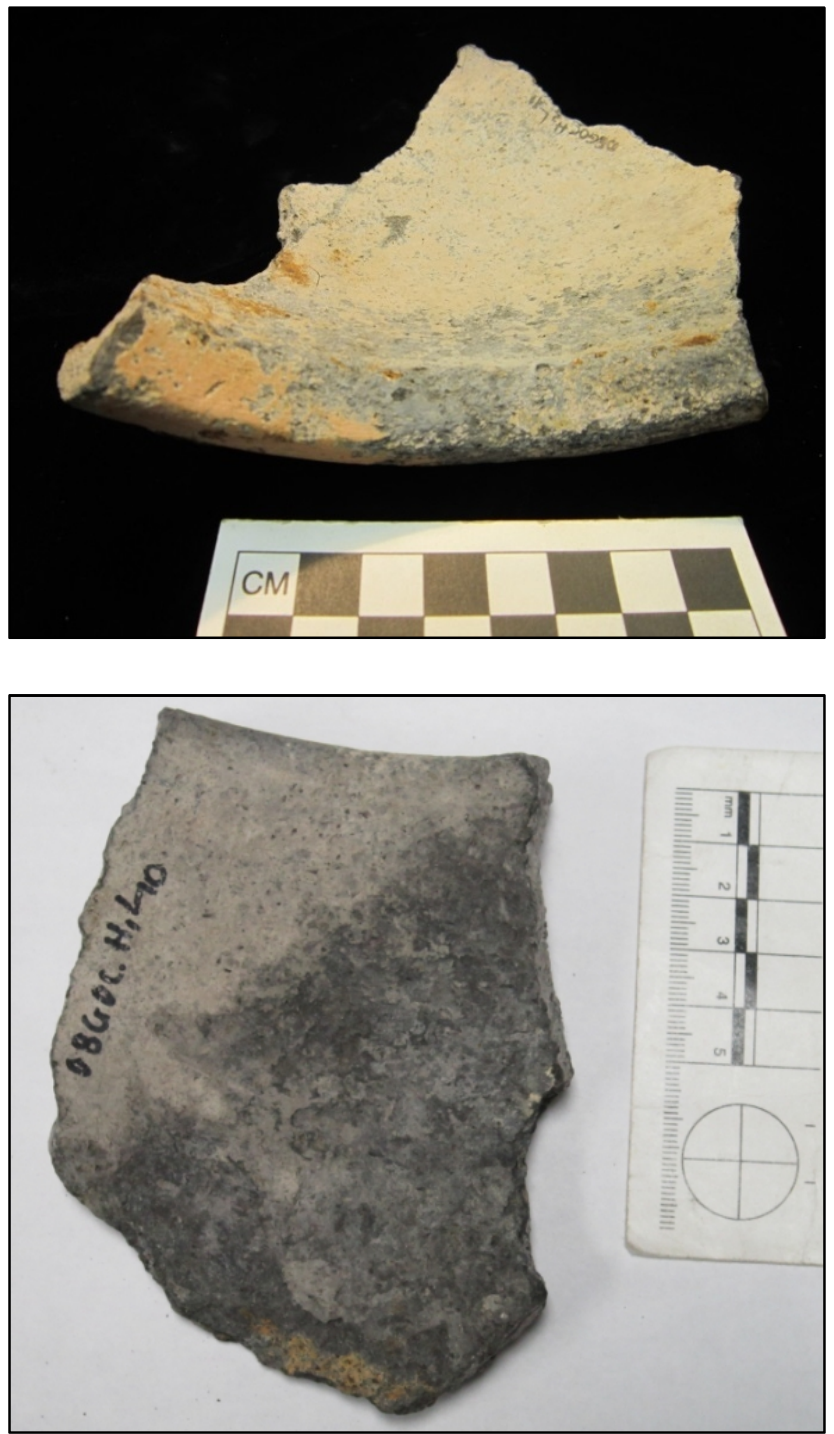

Figure 9: Pottery vessels from Gò Ô Chùa (top: Trench 2, Layer 11 and bottom: Trench 1. Layer 10) with non-abrasive surface attritions (pitting and surface erosions).

The majority of the vessels samples collected from Rạch Núi and An Sơn sites have cord marked exterior surfaces, while plain vessels dominate those from Gò Ô Chùa site. Aside from aesthetic purposes, texturing via cord marking, stamping, and impressing could have been intended to make the pottery vessels easier to handle, more durable (longer use-life), and/or more effective for cooking (Pierce 2005). Burnishing or coating was done to increase the resistance of the vessels to abrasion and decrease their permeability (Skibo et al. 1997).

The modern earthenware vessels in Vietnam that were used for experimental cooking and from two restaurants that serve Cá Kho Tộ (caramelized fish in clay pots, ethnographic) have forms similar to open bowls, are colored brown, and contain sand and shell temper (very fine - medium/coarse, 20\%). Cross sections/temper composition is most similar to those from Rạch Núi, and the shape is most similar to those from An Sơn. Small pots have double functions of cooking/heating and serving.

\section{Organic Residue Analysis}

The results of organic residue analysis with GC-MS are presented in Tables 3 and 4. Both modern and archaeological samples yielded appreciable amounts of fatty acids (Table 3). It should be noted that the ideal yield for residue analysis in terms of total lipid extract (TLE) is at least $5 \mu \mathrm{g} / \mathrm{g}$ (Charters et al. 1997). Data recovered to date only show the fatty acids from the acidic fractions of the TLEs that were converted to FAMEs, analyzed with GC-MS, identified, and quantified. Sample A4 should yield more than $5 \mu \mathrm{g} / \mathrm{g}$ (mass of lipid in $1 \mathrm{~g}$ of pottery powder) if nonfatty acid lipids in their neutral fractions are also derivatized into trimethylsilyl derivatives and analyzed. Table 4 lists the detected and identified fatty acids in each sample.

Table 3. Samples from Southern Vietnam included in preliminary analysis

\begin{tabular}{|c|c|c|}
\hline Sample & Description & $\begin{array}{l}\text { Fatty } \\
\text { acid } \\
\text { yield } \\
(\mu \mathrm{g} / \mathrm{g})\end{array}$ \\
\hline E7 & $\begin{array}{c}\text { Fish pot (5x cooking with } 5 \text { freshwater } \\
\text { varieties in Vietnam) }\end{array}$ & 230 \\
\hline E10 & $\begin{array}{c}\text { Cá Kho Tộ } 1 \text { (braised caramelized fish in } \\
\text { clay pot, fish only, ethnographic pot from } \\
\text { Phong An restaurant) }\end{array}$ & 408.9 \\
\hline E11 & $\begin{array}{l}\text { Cá Kho Tộ } 2 \text { (fish with pork fat, } \\
\text { ethnographic pot from Thuy Ta restaurant) }\end{array}$ & 647.5 \\
\hline A1 & $\begin{array}{c}\text { 12RNH3L2/20D4, Layer 2, } 2012 \text { Trench 3, } \\
\text { Rạch Núi }\end{array}$ & 17.04 \\
\hline $\mathrm{A} 2$ & $\begin{array}{c}\text { 12RNH1F2E/4c.1007-1, Feature 2, } 2012 \\
\text { Trench 1, Rạch Núi }\end{array}$ & 15.54 \\
\hline A3 & $\begin{array}{c}\text { 09ASH2L2-3 C3-1 ST, 20-30cm, } 2009 \\
\text { Trench 2, An Sơn }\end{array}$ & 9.47 \\
\hline A4 & $\begin{array}{c}\text { ASH1L12-13-1 ST, Layers 12-13, } 2009 \\
\text { Trench 1, An Sơn } \\
\text { 08GOCH1L11-1 }\end{array}$ & 4.63 \\
\hline A5 & $\begin{array}{c}\text { Layer 11, } 2008 \text { Trench 1, Northern Mound } \\
\text { of Gò Ô Chùa } \\
\text { 08GOCH1L11-3 }\end{array}$ & 66.92 \\
\hline A6 & $\begin{array}{c}\text { Layer 11, } 2008 \text { Trench 1, Northern Mound } \\
\text { of Gò Ô Chùa }\end{array}$ & 11.94 \\
\hline
\end{tabular}

Experimental pottery

From the organic residue analysis of the first pot used for experimental cooking of freshwater fish (E7, Figure 2), results show that a range of fatty acids from lauric $(\mathrm{C} 12)$ to nervonic (C24:1) acid were detected (Suppl. Fig. S9). Erucic (C22:1) and C24:1 acids are indicators of aquatic resources (Cramp and Evershed 2014). Based on the fragmentation patterns from mass spectra, $\omega$-(oalkylphenyl)alkanoic acids, which are stable biomarkers for aquatic resources (Cramp and Evershed 2014), from C16:n ( $\mathrm{n}=1-3, \mathrm{~m} / \mathrm{z}=105,262)$ were detected in this pot. Those from $\mathrm{C} 18-\mathrm{C} 22$ were not detected due possibly to the fact that the temperature of the pot during the experimental cooking did not reach the requisite temperature of $270^{\circ} \mathrm{C}$ to produce many of these $\omega$-(oalkylphenyl)alkanoic acids (Evershed et al. 2008), since boiling does not usually reach a pottery temperature of $300^{\circ} \mathrm{C}$ at which point when food begins to char (Skibo 2013) 
Table 4. Common fatty acids detected in modern (E) and archaeological samples (A). Legends: $\mathrm{C12}=$ lauric acid, C14 =myristic acid, C16 = palmitic acid, C16: 1 = palmitoleic acid, $\mathrm{C17}=$ margaric acid, $\mathrm{C} 18=$ stearic acid, C18:1 = oleic acid, C18:2 = linoleic acid, C19 = nonadecanoic acid, $\mathrm{C20}=$ arachidic acid, $\mathrm{C20} 11=$ gadoleic acid, C20:2 = eicosadienoic acid, C22 = behenic acid, C22:1 = erucic acid, C23 = tricosanoic acid, C24 = lignoceric acid, and C24:1 = nervonic acid.

\begin{tabular}{|c|c|c|c|c|c|c|c|c|c|c|c|c|c|c|c|c|c|}
\hline & C12 & C14 & C16 & C16:1 & C17 & C18 & $\begin{array}{c}\text { C18:1- } \\
9\end{array}$ & C18:2 & C19 & $\mathrm{C} 20$ & C20:1 & C20:2 & $\mathrm{C} 22$ & C22:1 & $\mathrm{C} 23$ & C24 & C24:1 \\
\hline E7 & $x$ & $x$ & $x$ & $x$ & $x$ & $x$ & $x$ & $x$ & $x$ & $x$ & $x$ & & $x$ & $x$ & $x$ & $x$ & $x$ \\
\hline E10 & $x$ & $x$ & $x$ & $x$ & $x$ & $x$ & $x$ & $x$ & $x$ & $x$ & $x$ & $x$ & $x$ & & $x$ & $x$ & $x$ \\
\hline E11 & $x$ & $x$ & $x$ & $x$ & $x$ & $x$ & $x$ & $x$ & & $x$ & $x$ & $x$ & $x$ & $x$ & $x$ & $x$ & \\
\hline $\mathrm{A} 1$ & & & $x$ & & & $x$ & $x$ & & & & & & & & & & \\
\hline A2 & & & $x$ & & & $x$ & $x$ & & & & & & & & & & \\
\hline A3 & & $x$ & $x$ & & & $x$ & $x$ & & & & & & & & & & \\
\hline $\mathrm{A} 4$ & & & $x$ & & & $x$ & & & & & & & & & & & \\
\hline A5 & & & $x$ & & $x$ & $x$ & $x$ & & & $x$ & & & $x$ & & $x$ & $x$ & \\
\hline A6 & & & $x$ & & & $x$ & $x$ & & & & & & & & & & \\
\hline
\end{tabular}

\section{Ethnographic pottery}

The analyzed ethnographic pots (E10 and E11) were both used to prepare and serve a southern Vietnamese dish, which is Cá Kho Tộ (braised caramelized fish in clay pot), but from different restaurants in Long An, Vietnam. The cook at Thuy Ta Restaurant added pork fat during preparation using the second pot (E11), a technique not practiced at the Phong An restaurant where the first pot (E10, Figure 4) came from. Thus, the actual goal for their analysis is to assess the effect of pork fat being mixed with fish and other ingredients in the resulting analytical data. The results from the ethnographic pots also show the range of fatty acids detected from the experimental pot used for cooking freshwater fish from southern Vietnam (E7), with an addition of eicosadienoic (C20:2) acid (Suppl. Figs. S10-11). Nonadecanoic (C19) and nervonic (C24:1) acids are missing in the second pot (E11). They were probably masked by fats from pork. In both pots, the amount of oleic acid is less than that of palmitic acid $(\mathrm{C} 18: 1<\mathrm{C} 16)$. Also, the amount of $\mathrm{C} 16$ is twice that of stearic acid $(\mathrm{C} 16 \approx 2 \mathrm{C} 18)$ in these ethnographic pots (E10 and E11) and the experimental pot used to cook fish (E7), which supports the identification of fish based on $n$ alkanoic acid profile (Olsson and Isaksson 2008). Based on the fragmentation patterns from their mass spectra, $\omega$ (o-alkylphenyl)alkanoic acids from C16:n $(\mathrm{n}=1-3, \mathrm{~m} / \mathrm{z}=$ $105,262)$ and $C 18: \mathrm{n}(\mathrm{m} / \mathrm{z}=105,290)$ were detected in both pots. The $\omega$-(o-alkylphenyl)alkanoic acids from $\mathrm{C} 20: \mathrm{n}$ (and/or C22:n) must at least be detected along with those from C16:n and C18:n to ensure that the $\omega^{-}-(\mathrm{o}-$ alkylphenyl)alkanoic acids came from the aquatic resources. Those from C16:n and C18:n can also be produced by heating vegetable oils (Cramp and Evershed 2014), which are a common ingredient used in stir frying. Since the mode of cooking is stir frying or dry cooking, the temperature of the pottery was able to reach 300$400^{\circ} \mathrm{C}$ (Skibo 2013), which is more than enough to produce the $\dot{\omega}$-(o-alkylphenyl)alkanoic acids from unsaturated fatty acids (Evershed et al. 2008).

\section{Archaeological pottery}

Among the archaeological pots sampled for preliminary study, one (A5) of the two sherds recovered from the earliest occupational layer at Gò Ô Chùa site had the greatest number of detected fatty acids (Figure 8, Table 4, Suppl. Fig. S12). In contrast to the three modern samples, oleic acid (C18:1) is less abundant than stearic (C18) acid. Palmitic (C16) acid seems to be about as thrice as abundant as stearic (C18), which possibly indicates a plant source (Gunstone 2004) or aquatic source (Olsson and Isaksson 2008). This is in contrast to the modern pots, where palmitic (C16) acid seems to be only as twice as abundant as stearic (C18), and the five other archaeological pots, where palmitic (C16) acid is less abundant than stearic (C18). The prominence of lignoceric acid (C24), with the detection of arachidic (C20) and behenic (C22) acids, point to the possibility of detecting seed plant sources (Fankhauser 1994), such as mung beans (Zia-Ul-Haq et al. 2008). These beans were introduced into MSEA from South Asia during the Metal Age (Castillo and Fuller 2010). The detection of C24 and hexacosanoic acid (C26) acid points to the possibilities of nonfood sources being processed in this pot, such as beeswax (Evershed et al. 1997). Tricosanic (C23) acid can also be found in some types of freshwater fishes (Mohamed 2013), and it was detected in this pot and the modern pot samples (E7, E10, and E11). It can be tentatively assessed this vessel (A5) from Gò Ô Chùa could have been used to prepare plant sources and/or aquatic resources.

The rest of the archaeological samples exhibited few fatty acids, but all produced $\mathrm{C} 16$ and C18. These two fatty acids are usually the most abundant in the archaeological record and can be further analyzed for $\delta^{13} \mathrm{C}$ values to clarify the source of organic residues (Dudd and Evershed 1998). All except A4 has oleic acid (C18:1). Only A3 has myristic acid (C14). Other fatty acids (such as C12, C14, C16:1, C18:1, and C18:2) may be lost and/or altered due to taphonomic processes, preservation conditions, and 
post-excavation processing (e.g., washing of pots). The rest of the archaeological samples have only a few fatty acids.

\section{PRELIMINARY CONCLUSIONS AND FURTHER WORK}

In sum, technofunctional analysis shows that restricted pots could have been used as cooking pots, since restricted openings can retain heat and moisture (Rice 1987; Reid 1989). Those identified as jars and restricted pots/jars could have been used for storage of water or other liquids, fermentation of food items, and/or transport. They also tend to have restricted openings to avoid spillage. Open pots, open bowls, restricted bowls, and small cups and/or bowls could have been used for serving food (with dipping access) or drinks (with pouring access) (Rice 1987). However, they could have also been used for cooking or maybe heating of food to be served. This probability is based on the observation in southern Vietnam that the earthenware vessels for cooking, as well as for heating and serving in restaurants have unrestricted forms similar to those of open bowls and small cups and/or bowls. The earthenware stoves from An Sơn have textured exteriors (cordmarked), which are different from the present-day plain stoves. Texturing of the stoves in An Sorn could have the same principle as texturing the cooking pots, which is for longer use-life and cooking efficiency (Pierce 2005). The detection of known biomarkers for aquatic resources seems to be challenging even for modern earthenware pots used for cooking aquatic resources. This needs further exploration. Organic residue analysis of a few archaeological samples demonstrates the potential of detecting plant sources and even nonfood sources in the pottery from prehistoric southern Vietnam.

This research is a work in progress, and all presented results in this paper are preliminary. Further work involves other experimental pots used for cooking other important food items in SEA, technofunctional and organic residue analyses of more archaeological pottery samples from the region, and compound specific isotopic analysis. Results will allow me to clarify the association of identified food residues with inferred form and function of sampled pottery vessels, and assess how specific food categories were prepared and/or served. It is expected that the pottery vessels classified as cooking pots were used to boil a single food item if only a single source of food residues is identified and/or were used to prepare stews, soups, or stir fried dishes if mixing of two or more food items is detected from organic residue analysis. For those classified as storage vessels without interior pitting, it is expected that a single food or drink item was stored on them if only a single source of residues is identified. If mixing of two or more food or liquid items is detected, the storage vessels were used for storing a prepared dish or drink. If one or more food or liquid items were identified in storage vessels with interior pitting, fermentation or brewing was the method of preparation done. No altered products due to cooking must be detected from organic residue analysis. If the serving vessels were actually used to serve food and drinks, cooked or raw, single or mixed food items are expected to be identified. These results will also allow me to address how social diversity or identity in prehistoric SEA is expressed based on the manner in which diverse communities processed, cooked, and served their food using pottery vessels.

\section{ACKNOWLEDGMENTS}

I am grateful for my active collaboration with the Australia National University (Assoc. Prof. Marc Oxenham, Dr. Philip Piper, Prof. Peter Bellwood, and Dr. Hsiao-Chun Hung), Center for Archaeological Studies, Southern Institute of Sustainable Development (Nguyen Khanh Trung Kien, Dang Ngoc Kinh and Bùi Chí Hoàng), and Long An Provincial Museum (Bui Phat Diem, Vuong Thu Hong, Van Ngoc Bich, Do Thi Lan, Nguyen Thi Sau, Tran Thi Kim Quy and Nguyen Thi Hong Tri). At University of Florida (UF), I am thankful to Dr. John Krigbaum and Dr. Neill Wallis for supervision and access to the facilities of Florida Museum of Natural History. I am indebted to Dr. Timothy Garrett for technical assistance and access to Biomedical Mass Spectrometry Core, Clinical and Translational Science Institute (UF). Thanks are also due to Fredeliza Campos, Dr. Carmen Sarjeant, Dr. Nguyen Kim Dung, Anna Willis, Luu Quoc Cuong, La Ngoc Diep, Dr. Cynthianne Spiteri, Dr. Maria Cristina Dancel, Ann Cordell, Dr. Eoin Quinlivan, Dr. Sergui Palii, and Dr. Andreas Reinecke. The James C. Waggoner Jr. Grants-In-Aid Award, John M. Goggin Research Award, Department of Anthropology Travel Award, Office of Research, Graduate Student Council Conference Travel Grant (UF), and Wenner-Gren Foundation Conference Grant provided financial support.

\section{REFERENCES}

Atalay, S. and C.A. Hastorf. 2006. Food, Meals, and Daily Activities: Food Habitus at Neolithic Catalhöyük. American Antiquity 71: 283-319.

Bellwood, P. 2005. First Farmers: The Origins of Agricultural Societies. Oxford: Blackwell Publishing.

Bellwood, P., M. Oxenham, Bui C.H., Nguyen T.K.D., A. Willis, C. Sarjeant, P. Piper, H. Matsumura, K. Tanaka, N. Beavan, T. Higham, Nguyen Q.M., Dan N.K., Nguyen K.T.K., Vo T.H., Van N.B., Tran T.K.Q, Nguyen P.T., F. Campos, Y.-I. Sato, Nguyen L.C., and N. Amano. 2011. An Sorn and the Neolithic of Southern Vietnam. Asian Perspectives 50: 144-175.

Berthouly-Salazar, C., N. Van, M. Gelyl, C. Vu Chi, M. TixierBoichard, N. Bruneau, E. Verrier, J.C. Maillard, and J.R. Michaux. 2010. Vietnamese Chickens: A Gate Towards Asian Genetic Diversity. BMC Genetics 11: 53-64.

Blench, R. 2015 (forthcoming). Reconstructing Austroasiatic Prehistory. In M. Jenny and P. Sidwell (eds.), Handbook of Austroasiatic Languages. Leiden: Brill.

Bronitsky, G. and R. Hamer. 1986. Experiments in Ceramic Technology: The Effects of Various Tempering Materials 
on Impact and Thermal-Shock Resistance. American Antiquity 51: 89-101.

Campos, F.Z. 2014. A Preliminary Report on the Analysis of Fish Bones Recovered from the 2012 Rạch Núi Archaeological Excavation in Southern Vietnam. Unpublished report.

Castillo, C. 2014. Rạch Núi: A Very Preliminary Archaeobotanical Report Focusing on the Identification of Millet Setaria italica. Unpublished report.

Castillo, C. and D. Fuller. 2010. Still too Fragmentary and Dependent Upon Chance? Advances in the Study of Early Southeast Asian Archaeobotany. In B. Bellina, E.A. Bacus, T. O. Pryce, and J.W. Christie (eds.), 50 Years of Archaeology in Southeast Asia: Essays in Honour of Ian Glover, pp. 93-111. Bangkok: River Books.

Charters, S., R. P. Evershed, A. Quye, P. W. Blinkhorn, and V. Reeves. 1997. Simulation Experiments for Determining the Use of Ancient Pottery Vessels: The Behaviour of Epicuticular Leaf Wax during Boiling of a Leafy Vegetable. Journal of Archaeological Science 24: 1-7.

Copley, M., K. Clark, and R. Evershed. 2005. Organic residue analysis of pottery vessels and clay balls. In I. Hodder (ed.), Changing Materialities at Çatalhöyük: Reports from the 1995-99 Seasons, pp. 169-174. Monograph No. 39. London: McDonald Institute for Archaeological Research / British Institute of Archaeology at Ankara.

Craig, O.E., H. Saul, A. Lucquin, Y. Nishida, K. Tache, L. Clarke, A. Thompson, D.T. Altoft, J. Uchiyama, M. Ajimoto, K. Gibbs, S. Isaksson, C.P. Heron, and P. Jordan. 2013. Earliest Evidence for the Use of Pottery. Nature 496:351-354.

Craig, O.E., V.J. Steele, A. Fischer, S. Hartz, S.H. Andersen, P. Donohoe, A. Glykou, H. Saul, D.M. Jones, E. Koch, and C.P. Heron. 2011. Ancient Lipids Reveal Continuity in Culinary Practices Across the Transition to Agriculture in Northern Europe. Proceedings of the National Academy of Sciences 108: 17910-17915.

Cramp, L. and R.P. Evershed. 2014. Reconstructing Aquatic Resource Exploitation in Human Prehistory using Lipid Biomarkers and Stable Isotopes. In T. Cerling (ed.), Treatise on Geochemistry: Archaeology and Anthropology, pp. 319-339. Oxford: Elsevier.

Cramp, L.J.E., J. Jones, A. Sheridan, J. Smyth, H. Whelton, J. Mulville, N. Sharples, and R.P. Evershed. 2014. Immediate Replacement of Fishing with Dairying by the Earliest Farmers of the Northeast Atlantic Archipelagos. Proceedings of the Royal Society B 281: 20140819.

Evershed, R.P. 2008. Organic Residue Analysis in Archaeology: The Archaeological Biomarker Revolution. Archaeometry 50: 895-924.

Evershed, R. P., M. S. Copley, L. Dickson, and F. A. Hansel. 2008. Experimental Evidence for the Processing of Marine Animal Products and Other Commodities Containing Polyunsaturated Fatty Acids in Pottery Vessels. Archaeometry 50: 101-113.

Evershed, R.P., S.J. Vaughan, S.N. Dudd, and J.S. Coles. 1997. Beeswax in lamps and conical cups from Late Minoan Crete. Antiquity 71: 979-985.

Fankhauser, B. 1994. Protein and Lipid Analysis of Food Residues. In J.G. Hather (ed.), Tropical Archaeobotany: Applications and New Developments, pp. 227-250. London: Routledge.
Gibbs, K. and P. Jordan. 2013. Bridging the Boreal Forest: Siberian Archaeology and the Emergence of Pottery among Prehistoric Hunter-Gatherers of Northern Eurasia. Sibirica 12: 1-38.

Gunstone, F.D. 2004. The Chemistry of Oils and Fats: Sources, Composition, Properties and Uses. Oxford: Blackwell.

Hally, D.J. 1983. Use Alteration of Pottery Vessel Surfaces: An Important Source of Evidence for the Identification of Vessel Function. North American Archaeologist 4: 3-26.

Hauman, C. 2012. What's Cooking? An Archaeological Residue Analysis of Ceramics from Thailand. Unpublished M.A. Dissertation, University of Otago, Dunedin.

Heron, C. and R. Evershed. 1993. The Analysis of Organic Residues and the Study of Pottery Use. In M.B. Shiffer (ed.), Archaeological Method and Theory, pp. 247-284. Tuczon: University of Arizona Press.

Higham, C.F.W. 2002. Early Cultures of Mainland Southeast Asia. Bangkok: River Books.

2014. Early Mainland Southeast Asia: From First Humans to Angkor. Bangkok: River Books.

Hodder, I. 2012. Entangled: An Archaeology of the Relationships between Humans and Things. Malden: Wiley-Blackwell.

Jones, A. 1999. The World on a Plate: Ceramics, Food Technology and Cosmology in Neolithic Orkney. World Archaeology 31: 55-77.

Kobayashi, M. 1994. Use-Alteration Analysis of Kalinga Pottery: Interior Carbon Deposits of Cooking Pots. In W. A. Longacre and J. M. Skibo (eds.), Kalinga Ethnoarchaeology, pp. 127-168. Washington, D.C.: Smithsonian Institution Press.

Miksic, J. (ed.) 2003. Earthenware in Southeast Asia. Singapore: Singapore University Press.

Mohamed, E.H.A. 2013. Fatty Acids Composition and Profile in Fat and Muscle Oil of the Nile Fish Polypterus Senegalus (Cuvier, 1829) from Sudan. American Journal of Research Communication 1: 152-166.

Olsson, M. and S. Isaksson. 2008. Molecular and Isotopic Traces of Cooking and Consumption of Fish at an Early Medieval Manor Site in Eastern Middle Sweden. Journal of Archaeological Science 35: 773-780.

Orton, C., P. Tyers, and A.G. Vince. 1993. Pottery in Archaeology. Cambridge: Cambridge University Press, C.

Pierce, C. 2005. Reverse Engineering the Ceramic Cooking Pot: Cost and Performance Properties of Plain and Textured Vessels. Journal of Archaeological Method and Theory 12: 117-157.

Piper, P.J. and N. Amano. 2014. A Preliminary Report on the Terrestrial Vertebrate Remains from Rạch Núi, Long An Province, Vietnam. Unpublished report.

Piper, P. J., F. Z. Campos, D.N. Kinh, N. Amano, M. Oxenham, B.C. Hoang, P. Bellwood, and A. Willis. 2012. Early Evidence for Pig and Dog Husbandry from the Neolithic Site of An Sơn, Southern Vietnam. International Journal of Osteoarchaeology DOI: 10.1002/oa.2226.

Piper, P.J., M. Oxenham, N. Amano, P. Bellwood, F. Campos, C. Castillo, J. Ceron, M. Eusebio, Bui C.H., Nguyen K., C. Sarjeant, Thu H.V., and R. Wood. 2014. Preliminary Report on the 2012 Excavations at Rạch Núi, Long An Province, Vietnam. Unpublished report. 
Reid, K.C. 1989. A Materials Science Perspective on HunterGatherer Pottery. In G. Bronitsky (ed.), Pottery Technology: Ideas and Approaches, pp. 167-180. Boulder: Westview Press.

Reinecke, A. 2012. The Prehistoric Occupation and Cultural Characteristics of the Mekong Delta during the Pre-Funan Periods. In D. Bonatz, A. Reinecke, M.L. Tjoa-Bonatz (eds.), Crossing Borders: Selected Papers from the 13th International Conference of the European Association of Southeast Asian Archaeologists, Volume 1, pp. 239-256, Singapore: National University of Singapore Press. 2013. personal communications.

Rice, P.M. 1987. Pottery Analysis: A Sourcebook. Chicago: University of Chicago.

Rispoli, F. 2007. The Incised \& Impressed Pottery Style of Mainland Southeast Asia: Following the Paths of Neolithization. East and West 57: 235-304.

Rye, O.S. 1976. Keeping Your Temper Under Control. Archaeology and Physical Anthropology in Oceania 11: 106-137.

1981. Pottery. Washington, D.C.: Taraxacum.

Sarjeant, C. 2012a. Defining the Neolithic of Southern Vietnam: The Ceramics of An Sorn. In D. Bonatz, A. Reinecke, and M.L. Tjoa-Bonatz (eds.), Crossing Borders: Selected Papers from the 13th International Conference of the European Association of Southeast Asian Archaeologists, Volume 1, pp. 143-163. Singapore: National University of Singapore.

2012b. The Role of Potters at Neolithic An Sơn, Southern Vietnam. Unpublished Ph.D. thesis, The Australian National University, Canberra.

Schiffer, M. B. and J.M. Skibo. 1987. Theory and Experiment in the Study of Technological Change. Current Anthropology 28: 595-622.

Skibo, J. 1992. Pottery Function: A Use-Alteration Perspective. New York: Plenum.

2013. Understanding Pottery Function. New York: Springer.

Skibo, J.M., T.C. Butts, and M.B. Schiffer. 1997. Ceramic Surface Treatment and Abrasion Resistance: An Experimental Study. Journal of Archaeological Science 24: 311-317.

Stockhammer, P.W. 2012. Performing the Practice Turn in Archaeology. Transcultural Studies 1: 7-42.

Twiss, K.C. 2012. The Archaeology of Food and Social Diversity. Journal of Archaeological Research 20: 357395.

Vuković, J.B. 2012. Non-abrasive Pottery Surface Attrition: Blagotin Evidence. Journal of Serbian Archaeological Society 25: 25-35.

Wallis, N.J. 2011. The Swift Creek Gift: Vessel Exchange on the Atlantic Coast. Tuscalossa: The University of Alabama Press.

Weber, S., H. Lehman, T. Barela, S. Hawks, and D. Harriman. 2010. Rice or Millets: Early Farming Strategies in Prehistoric Central Thailand. Archaeological and Anthropological Sciences 2: 79-88.

White, J.C. 2011. Emergence of Cultural Diversity in Mainland Southeast Asia: A View from Prehistory. In N.J. Enfield (ed.), Dynamics of Human Diversity: The Case of
Mainland Southeast Asia, pp. 9-46. Canberra: Pacific Linguistics.

Wiley, G.R. 1949. Archaeology of the Florida Gulf Coast. Smithsonian Miscellaneous Collections 113. Washington, D.C.: Smithsonian Institution.

Yang, F.-P. and R.J. March. 2012. Preliminary Study of Organic Matter in Ceramics from the Yiou-Hsian-Fan Site, Southern Taiwan: Anthropic or Natural Significance. Paper presented at the European Association of Southeast Asian Archaeologists $14^{\text {th }}$ International Meeting in Dublin, Ireland, September 18-21, 2012.

Zia-Ul-Haq, M., M. Ahmad, and S. Iqbal. 2008. Characteristics of Oil from Seeds of 4 Mungbean [Vigna radiata (L.) Wilczek] Cultivars Grown in Pakistan. Journal of American Oil Chemical Society 85: 851-856. 